\title{
Correction to: Ecotoxicity screening evaluation of selected pharmaceuticals and their transformation products towards various organisms
}

\author{
Łukasz Grabarczyk $^{1} \cdot$ Ewa Mulkiewicz ${ }^{1} \cdot$ Stefan Stolte $^{2} \cdot$ Alan Puckowski $^{1} \cdot$ Magdalena Pazda $^{1} \cdot$ Piotr Stepnowski $^{1}$. \\ Anna Białk-Bielińska ${ }^{1}$
}

(C) The Author(s) 2021

\section{Correction to: Environ Sci Pollut Res (2020) 27:26103-26114 \\ https://doi.org/10.1007/s11356-020-08881-3}

The correct Supplementary Material is presented in this paper.

Supplementary Information The online version contains supplementary material available at https://doi.org/10.1007/s11356-021-15410-3.

Open Access This article is licensed under a Creative Commons Attribution 4.0 International License, which permits use, sharing, adaptation, distribution and reproduction in any medium or format, as long as you give appropriate credit to the original author(s) and the source, provide a link to the Creative Commons licence, and indicate if changes were made. The images or other third party material in this article are included in the article's Creative Commons licence, unless indicated otherwise in a credit line to the material. If material is not included in the article's Creative Commons licence and your intended use is not permitted by statutory regulation or exceeds the permitted use, you will need to obtain permission directly from the copyright holder. To view a copy of this licence, visit http://creativecommons.org/licenses/by/4.0/.

Publisher's note Springer Nature remains neutral with regard to jurisdictional claims in published maps and institutional affiliations.

The online version of the original article can be found at https://doi.org/ 10.1007/s11356-020-08881-3

Ewa Mulkiewicz

ewa.mulkiewicz@ug.edu.pl

1 Department of Environmental Analysis, Faculty of Chemistry, University of Gdańsk, ul. Wita Stwosza 63, 80-308 Gdańsk, Poland

2 Institute of Water Chemistry, Technische Universität Dresden, 01062 Dresden, Germany 